\title{
Relationships among nutrient inputs, water nutrient concentrations, primary production, and yield of Oreochromis niloticus in ponds
}

\author{
James S. Diana, C. Kwei Lin* and Phillip J. Schneeberger \\ Great Lakes Research Division and School of Natural Resources, University of Michigan, Ann Arbor. \\ MI 48109-1115, USA
}

(Accepted 5 July 1990)

\begin{abstract}
Diana, J.S., Lin, C.K. and Schneeberger, P.J., 1991. Relationships among nutrient inputs, water nutrient concentrations, primary production, and yield of Oreochromis niloticus in ponds. Aquacullure, 92: 323-341.

Experiments were run to assess the physical, chemical, and biological processes leading to increased production of fertilized fish ponds in Thailand for approximately 5 months during wet season 1984 and wet and dry seasons 1985 . Eight or 12 ponds $\left(250 \mathrm{~m}^{2}\right)$ were stocked with male Nile tilapia at 1 fish $/ \mathrm{m}^{3}$. Ponds received fertilizer according to three different schemes: (1) low input inorganic $(0.27$ $\mathrm{kg}$ triple superphosphate, equalling $0.12 \mathrm{~kg} \mathrm{P} \mathrm{ha}^{-1} \mathrm{~d}^{-1}$ ); (2) high input organic ( $71.4 \mathrm{dry} \mathrm{kg} \mathrm{chicken}$ manure ha-1 $\mathrm{d}^{-1}$ ); and (3) high input inorganic ( $14.3 \mathrm{~kg}$ triple superphosphate ha-1 $\mathrm{d}^{-1}$ and $4.3 \mathrm{~kg}$ urea ha- $\mathrm{h}^{-1}$ ). Treatments 2 and 3 yielded identical loadings of $2 \mathrm{~kg} \mathrm{~N} \mathrm{ha}^{-1} \mathrm{~d}^{-1}$ and $3.2 \mathrm{~kg} \mathrm{Pha}^{-1}$ $d^{-1}$.

Ponds receiving high fertilizer inputs had higher nutrient concentrations in water, higher primary production, and higher fish production than ponds treated with low fertilizer inputs. At high fertilizer inputs, chlorophyll $a$ content and primary production were similar for all ponds, but fish growth and adult yield were significantly greater in organically rather than inorganically fertilized ponds. This was attributed to increased heterotrophy by fish in ponds treated with organic fertilizer. Regression analysis indicated only marginally predictive relationships between total inorganic nitrogen or total phosphorus concentration in the water and primary production. Secchi disk depth was a reasonable predictor of both primary production and chlorophyll $a\left(r^{2}=0.67\right)$. Diel temperature stratification was low, but correlated with air temperature, solar radiation, rainfall, and wind velocity. Diel oxygen stratification was more pronounced with inorganic fertilization, probably due to greater water clarity and more even distribution of primary production in organically fertilized ponds. Yield of stocked fish was correlated with rainfall and primary production.
\end{abstract}

*Present address: Agriculture and Food Engineering Division, Asian Institute of Technology Bangkok, Thailand. 


\section{INTRODUCTION}

Nile tilapia (Oreochromis niloticus) is commonly grown in ponds fertilized to increase primary and secondary production. Fertilization of fish ponds has been widely studied, with often conflicting results. Temperate ponds, with low stocking densities, seem to require only phosphorus addition (Yamada, 1986). In contrast, subtropical or tropical ponds with higher stocking densities achieve higher yields with nitrogen and phosphorus addition (Boyd, 1976). Phytoplankton have a N-P weight ratio approaching 10:1 (Goldman, 1980). The nitrogen requirement for ponds is also dependent on the amount of nitrogen fixation by aquatic communities (Colman and Edwards, 1987; Lin et al., 1988). Composition requirements for fertilizer may vary widely depending on local conditions.

A similar controversy exists between the use of organic or inorganic fertilizers. Inorganic fertilizer has been promoted as favorable due to its lower loading rates (due to higher nutrient contents) and lower oxygen demand (Yamada, 1986; Colman and Edwards, 1987). However, manure has often been demonstrated to increase fish yield beyond that expected from $\mathrm{N}$ and $\mathrm{P}$ addition alone (Schroeder, 1978; Noriega-Curtis, 1979). Organic fertilizers are believed to increase yield by three different processes: (1) direct consumption by fish, (2) utilization by other heterotrophic organisms, and (3) increased $N$ and $P$ available to phytoplankton (Tang, 1970). Only process 3 would occur in inorganically fertilized ponds. In addition, phosphates from inorganic fertilizer application often accumulate in pond sediments and are not available to phytoplankton (Hickling, 1962).

The purpose of this study was to examine relationships between the physical, chemical, and biological processes in ponds and fish yield under different fertilization regimes and climatic seasons. Fertilization regimes included low and high inputs of inorganic fertilizer, as well as a comparison of organic and inorganic fertilizers at equivalent high input levels. Some of the results described here have previously been presented at the Second International Symposium on Tilapia in Aquaculture (Diana et al., 1988b).

\section{MATERIALS AND METHODS}

Data for this study were collected at the Ayutthaya Freshwater Fisheries Station located at Bang Sai $\left(14^{\circ} 45^{\prime} \mathrm{N}, 100^{\circ} 32^{\prime} \mathrm{E}\right)$, approximately $60 \mathrm{~km}$ northwest of Bangkok, Thailand. Pond soil was slightly basic (pH 7.4) and impermeable. Ponds used in the experiments were $220 \mathrm{~m}^{3}$ in volume (surface area $250 \mathrm{~m}^{2}$ ) when filled to the normal water depth of $0.9 \mathrm{~m}$; water was pumped into individual ponds as necessary to maintain this depth. A narrow walkway was constructed extending from the banks to center of each pond, so samples and measurements could be made at a consistent location. 
Oreochromis niloticus were spawned in brood ponds, raised on site to about $25-35 \mathrm{~g}$, then male fish were manually sorted and stocked at $1 \mathrm{fish} / \mathrm{m}^{3}$, or 220 fish/pond. Each experiment lasted 5 months corresponding with annual wet or dry seasons.

A low nutrient input experiment was run in 12 replicate ponds during the wet season from August through December 1984. Triple superphosphate (TSP) was applied to each pond at a rate of $0.12 \mathrm{~kg}$ phosphorus ha- $\mathrm{h}^{-1} \mathrm{~d}^{-1}$. Fertilizer was applied biweekly by suspending measured amounts of TSP in a porous bag located in the upper $25 \mathrm{~cm}$ of the water column. This experiment was intended to determine pond dynamics and yield under very low management intensity.

High nutrient input experiments were run during the dry (February-June) and wet (August-December) seasons of 1985 . In each season, four ponds received organic fertilizer inputs in the form of locally available, layer chicken manure (assayed at 2.8-4.5-3.1 NPK by weight) at a ratc of $71.4 \mathrm{~kg} \mathrm{ha}^{-1}$ $\mathrm{d}^{-1}$. The other four ponds were treated with inorganic fertilizers: urea (47$0-0)$ was applied at $4.3 \mathrm{~kg} \mathrm{ha}^{-1} \mathrm{~d}^{-1}$ and TSP $(0-46-0)$ was added at a rate of $14.3 \mathrm{~kg} \mathrm{ha}^{-1} \mathrm{~d}^{-1}$. Loadings of nitrogen and phosphorus were identical between the two sets of ponds at $2 \mathrm{~kg}$ nitrogen $\mathrm{ha}^{-1} \mathrm{~d}^{-1}$ and $3.2 \mathrm{~kg}$ phosphorus $\mathrm{ha}^{-1} \mathrm{~d}^{-1}$.

Weather data (solar radiation, rainfall, and wind speed) were gathered daily. Solar radiation was measured in Einsteins $\mathrm{m}^{-2} \mathrm{~d}^{-1}$ by a LiCor Solar Monitor and a LiCor Quantum Sensor installed at the study site. Rainfall was determined from three rain gauges mounted at the pond sites. A Windscope Wind Speed and Direction Indicator provided daily wind speed readings.

Diel fluctuations in dissolved oxygen (DO) and temperature were measured once monthly at 4-h intervals, using a Yellow Springs Instrument (YSI) DO Meter with a Temperature Indicator. The DO meter was calibrated daily using air calibration, and compared once per month with the Winkler method (APHA, 1980). DO and temperature were measured at three levels in the water column: $25 \mathrm{~cm}$ below the surface, mid-water, and $25 \mathrm{~cm}$ above the pond bottom. Oxygen and temperature differentials at each 4-h sample were defined as the difference for each variable between top and bottom values.

Secchi disk depth and chlorophyll $a$ concentration were recorded weekly during the 1984 wet season and the 1985 dry season, and twice-weekly during the 1985 wet season. Visibility was calculated as the average depth at which the Secchi disk disappeared when lowered, and the depth at which it reappeared when raised (Lind, 1979). Chlorophyll $a$ was measured according to method detailed by Wetzel and Likens (1979), using one water sample per pond pooled from three $90-\mathrm{cm}$ column samples taken at $10.00 \mathrm{~h}$.

Concentrations of ammonia, nitrate, nitrite, and total phosphorus in water were measured using standard methods (APHA, 1980) monthly during the 1984 wet season, and weekly during the wet and dry seasons of 1985 . Water 
samples, taken by a PVC tube column sampler from three locations in each pond at $10.00 \mathrm{~h}$, were pooled and passed through a $25-\mu \mathrm{m}$ filter. Total ammonia was analyzed by the phenate procedure, nitrate by the phenoldisulfonic procedure, and nitrate was reduced to nitrite by cadmium column. Total inorganic nitrogen was calculated as the sum of the three inorganic nitrogen values. Unfiltered water samples were analyzed for total phosphorus using persulfate digestion procedure (APHA, 1980).

Primary production was determined monthly for the 1984 wet season and the 1985 dry season experiments, and weekly during the 1985 wet season. Two light and one dark bottles were filled with mixed column water and incubated horizontally $25 \mathrm{~cm}$ below the water surface in each pond for $3 \mathrm{~h}$ $(08.00-11.00 \mathrm{~h})$. The value $\left(\mathrm{mg} \mathrm{C} / \mathrm{m}^{3}\right)$ obtained during the incubation period was used to extrapolate the total productivity over the photoperiod of the day. The conversion factor was based on the solar radiation (Einsteins $\mathrm{m}^{-2} \mathrm{~h}^{-1}$ ) integrated over the incubation period and the corresponding daily photoperiod. Thus, this measure equates to gross primary productivity (McConnell et al., 1977). This method suffers from inability to estimate total water column production unless a volumetric approach is used (NoriegaCurtis, 1979). However, these values probably can be used in a comparative fashion among ponds treated similarly.

Fish stocked initially in each pond were sexed, counted, and batch weighed. Average weight of fish in each pond was estimated monthly by weighing fish samples representing about $10 \%$ of the initial number stocked. At termination of experiments, all ponds were drained and fish were removed, weighed, and counted. Monthly fish numbers were estimated by linear interpolation from the initial and final fish numbers. Total monthly biomass of adult (stocked) tilapia was calculated from mean individual weight multiplied by monthly number of fish. Offspring produced in the ponds were removed monthly by seine, weighed, and discarded. Net yield of adults each month $(m)$ was calculated by subtracting biomass at month $m-1$ from biomass at month $m$. Total net yield was the sum of net adult yield and total yield of offspring produced each month.

To standardize the data set, measurements made at daily, weekly, and biweekly intervals were averaged to obtain one value per calendar month. Analysis of variance (ANOVA) was used to determine differences between treatments (organic or inorganic fertilizer) or seasons, using an alpha level of 0.05 . High and low input experiments were not statistically compared, as the differences noted could result from yearly climatic differences between 1984 and 1985. Between-pond differences (within a treatment) were tested by comparing the monthly values of each parameter for each pond with ANOVA. Temperature differential and oxygen differential as dependent variables were compared by step-wise regression to physical and chemical variables to determine factors influencing stratification. Predictive relationships between adult 
fish yield or primary production as dependent variables and other physical, chemical, or biological variables were evaluated by regression. The significance level for all tests was set at 0.05 , and the program used was MIDAS (Fox and Guire, 1976).

\section{RESULTS}

\section{Climate}

Central Thailand has a monsoon climate with wet and dry seasons (Fig. 1 ). Average monthly rainfall was not significantly different each year during the dry season (February-June; ANOVA, $P<0.05$ ), although 1985 had a higher total rainfall in the dry season. However, for the two wet season experiments reported here, 1984 remained dry ( $40.2 \mathrm{~cm}$ overall), while rainfall was moderate during 1985 ( $569.7 \mathrm{~cm}$ overall ). Rainfall in the dry season of 1985 was $32.7 \mathrm{~cm}$.

The 1985 dry season was exceptionally warm; average maximum air temperature was $36.9^{\circ} \mathrm{C}$ and average minimum air temperature was $26.3^{\circ} \mathrm{C}$. Winds were generally calm (average $2.9 \mathrm{~km} / \mathrm{h}$ ). Average daily solar radiation was 38.9 Einsteins $\mathrm{m}^{-2} \mathrm{~d}^{-1}$. Air temperature in wet season 1985 was much cooler, with an average maximum of 32.6 and average minimum of $25.9^{\circ} \mathrm{C}$. Solar radiation $\left(30.3\right.$ Einsteins $\left.\mathrm{m}^{-2} \mathrm{~d}^{-1}\right)$ and wind speed $(1.3 \mathrm{~km} / \mathrm{h})$ were also lower than dry season values.

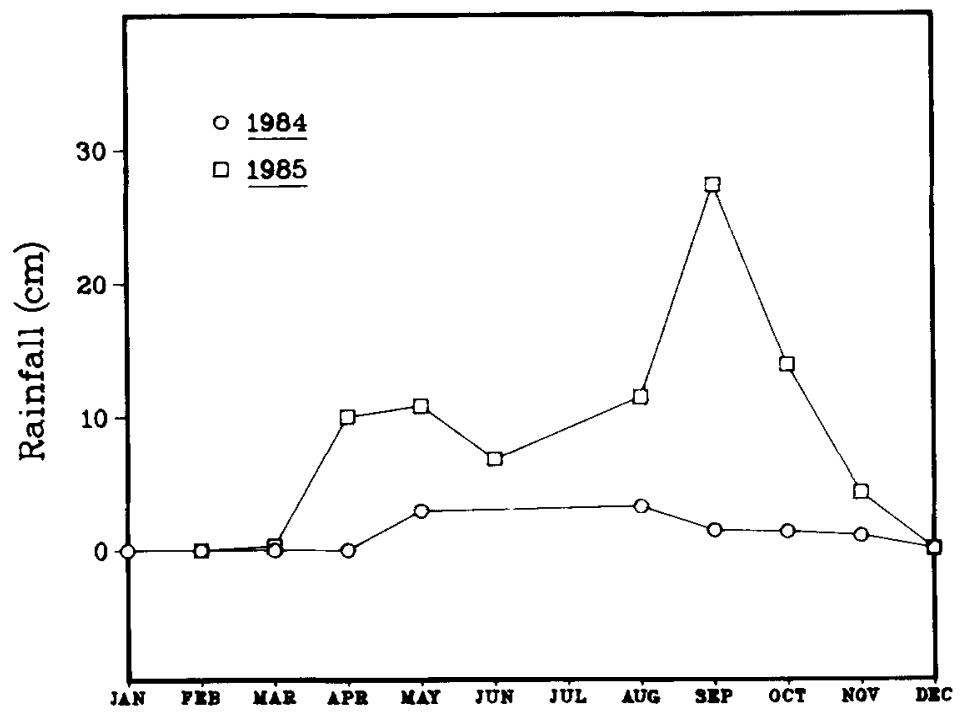

Fig. 1. Total monthly rainfall at experimental ponds for 1984 and 1985. 


\section{Physical and chemical parameters}

Bottom water temperature varied little between ponds for a sample date, but differed significantly between months. Average maximum monthly bottom water temperature was 29.5 in September, average minimum monthly bottom water temperature was 24.6 in December. Peak temperature stratification was observed regularly around $14.00 \mathrm{~h}$, with relatively small differentials (average $1.8^{\circ} \mathrm{C}$ ), and was not significantly different between treatments (ANOVA, $P<0.05$; Fig. 2 ). Average weekly maximum water temperature in dry season 1985 was $32.4^{\circ} \mathrm{C}$, while it was lower $\left(31.3^{\circ} \mathrm{C}\right)$ during the wet season. However, diel data for the two seasons showed no significant difference in water temperature, which was probably a coincidence related to the 5 days each season which were chosen for diel analyses.

There were no significant differences in total inorganic nitrogen between ponds within a treatment (defined as a unique fertilizer type and season), but there were differences among treatments (ANOVA, $P<0.05$; Fig. 3 ). The high input treatments had considerably higher average nitrogen concentration $(0.16 \mathrm{mg} / 1)$ than the low input treatment $(0.05 \mathrm{mg} / 1)$, except immediately after flooding when low input ponds had high nitrogen levels (Fig. 3 ). When high nutrient inputs were used, the organic treatment had a significantly lower nitrogen level than the inorganic one $(0.13 \mathrm{vs} .0 .20 \mathrm{mg} / \mathrm{l}, \mathrm{AN}$ -

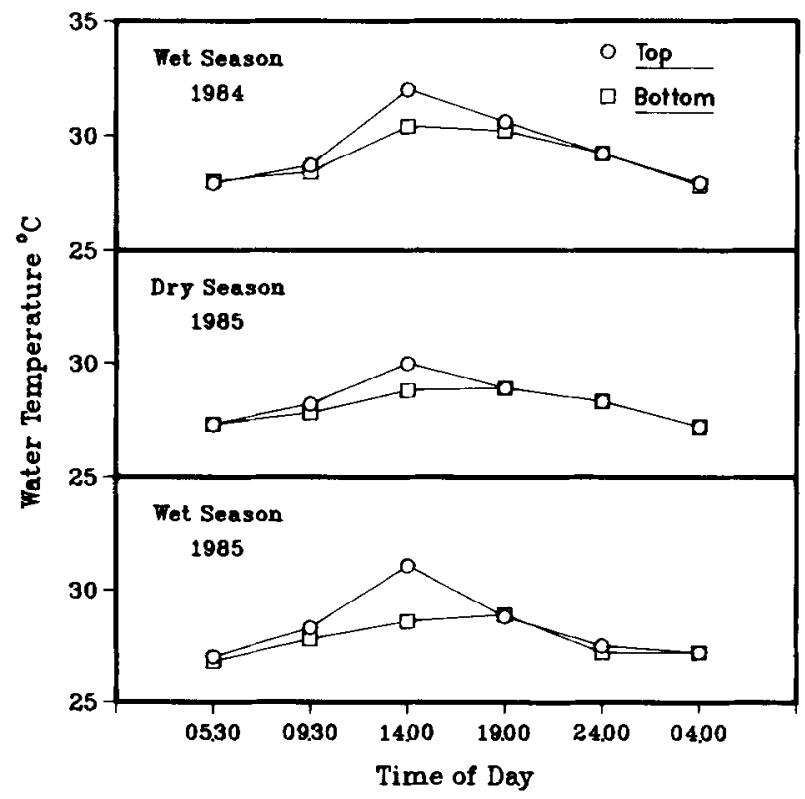

Fig. 2. Diel changes in the mean of monthly surface and bottom water temperatures for experimental ponds. Wet season $1984=$ low input inorganic experiment; 1985 data $=$ high input organic or inorganic experiments for each season. 


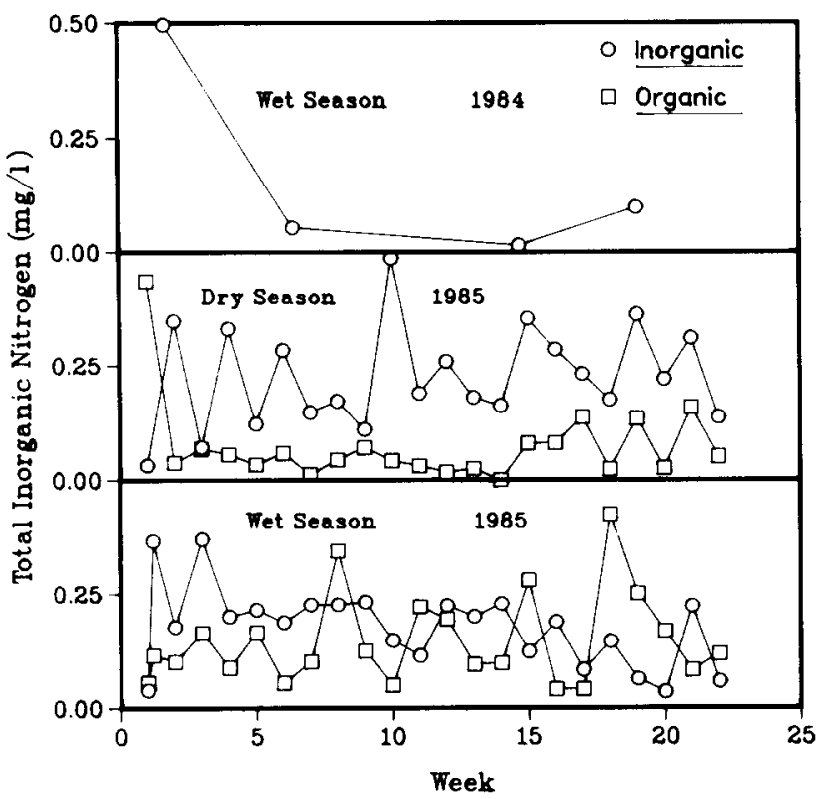

Fig. 3. Trends in mean total inorganic nitrogen in experimental ponds. Wet season $1984=$ low input inorganic experiment; 1985 data $=$ high input organic or inorganic experiments for each season.

OVA, $P<0.05)$. There was also a seasonal effect in 1985 , as average nitrogen levels were higher in both fertilizer treatments during the wet season. This was especially magnified with organic fertilization (dry season $=0.06 \mathrm{mg} / \mathrm{l}$, wet season $=0.19 \mathrm{mg} / \mathrm{l}$ ). Nitrate-nitrite was the predominant nitrogen in organically fertilized ponds, while ammonia predominated in inorganic treatments.

Total phosphorus in pond water was also dependent on fertilization. There were no significant differences between ponds within each treatment. However, mean phosphorus levels were related to input (Fig. 4). Low inorganic input ponds averaged $0.06 \mathrm{mg} \mathrm{P} / 1$, high organic input ponds $0.13 \mathrm{mg} \mathrm{P} / 1$, and high inorganic input ponds $0.84 \mathrm{mg} \mathrm{P} / \mathrm{l}$. There were significant time effects in all three treatments, although trends were not consistent. Comparing nitrogen and phosphorus in our samples it appears that nitrogen may have been a limiting factor to algal production, due to its lower concentration in the water and its higher requirement in algal cells.

Maximum oxygen concentrations were observed in mid-afternoon, with minimum in early morning $(05.30 \mathrm{~h})$. Average oxygen concentrations at dawn were about $5 \mathrm{mg} / \mathrm{l}$ and similar for all treatments and seasons. Oxygen stratification was often well developed in ponds with high nutrient input, and peak stratification occurred at $14.00 \mathrm{~h}$ (Fig. 5). Average vertical oxygen differential (oxygen at top minus oxygen at bottom of water column) was signifi- 


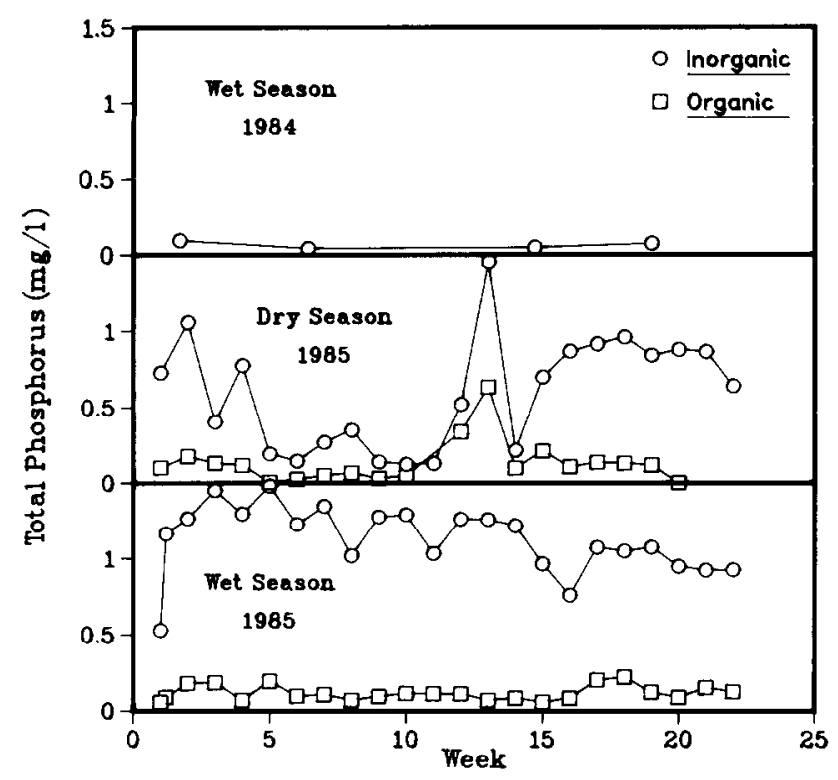

Fig. 4. Mean total phosphorus trends in experimental ponds. Wet season $1984=$ low input inorganic experiment; 1985 data = high input organic or inorganic experiments for each season.

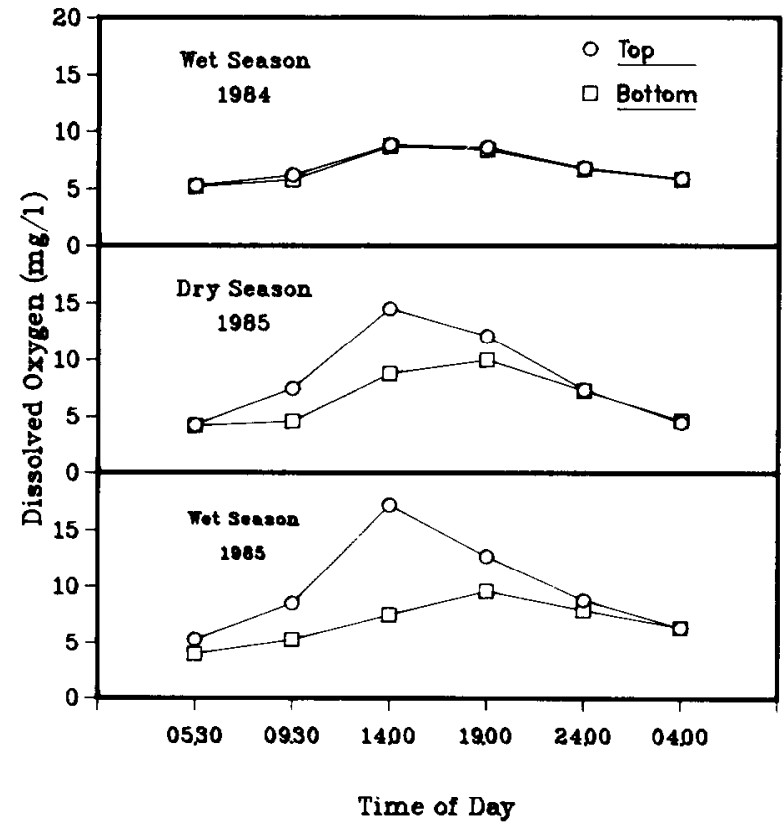

Fig. 5. Diel changes in the mean of monthly surface and bottom dissolved oxygen levels for experimental ponds enriched with inorganic fertilizers. Wet season $1984=$ low input; $1985=$ high input. 
cantly greater in inorganically fertilized ponds $(7.6 \mathrm{mg} / 1)$ than in organically fertilized ones $(3.0 \mathrm{mg} / 1$, ANOVA, $P<0.01$ ) (Fig. 6).

\section{Biological parameters}

There were no significant differences for Secchi disk depth between ponds in any fertilization and season treatment, but there was an inverse effect for nutrient input level on Secchi disk depth. Average Secchi disk values in organically and inorganically fertilized ponds were 30.0 and $19.9 \mathrm{~cm}$, respectively (Fig. 7). While there were significant differences in Secchi disk depth over months, this did not reflect a consistent increase or decrease over time.

Chlorophyll $a$ levels were not significantly different between ponds within a treatment. High nutrient inputs led to an average nine-fold increase in chlorophyll $a$ over low nutrient input (Fig. 8). There were no significant differences in average chlorophyll $a$ concentration between organically ( $96 \mathrm{mg} /$ $\mathrm{m}^{3}$ ) and inorganically $\left(125 \mathrm{mg} / \mathrm{m}^{3}\right)$ fertilized ponds at high nutrient inputs, due to high variability in observations. There were significant time trends in chlorophyll $a$ for each fertilization treatment, but these trends were inconsistent.

Primary production showed trends similar to chlorophyll $a$, with no significant differences between ponds for each treatment, increased average pro-

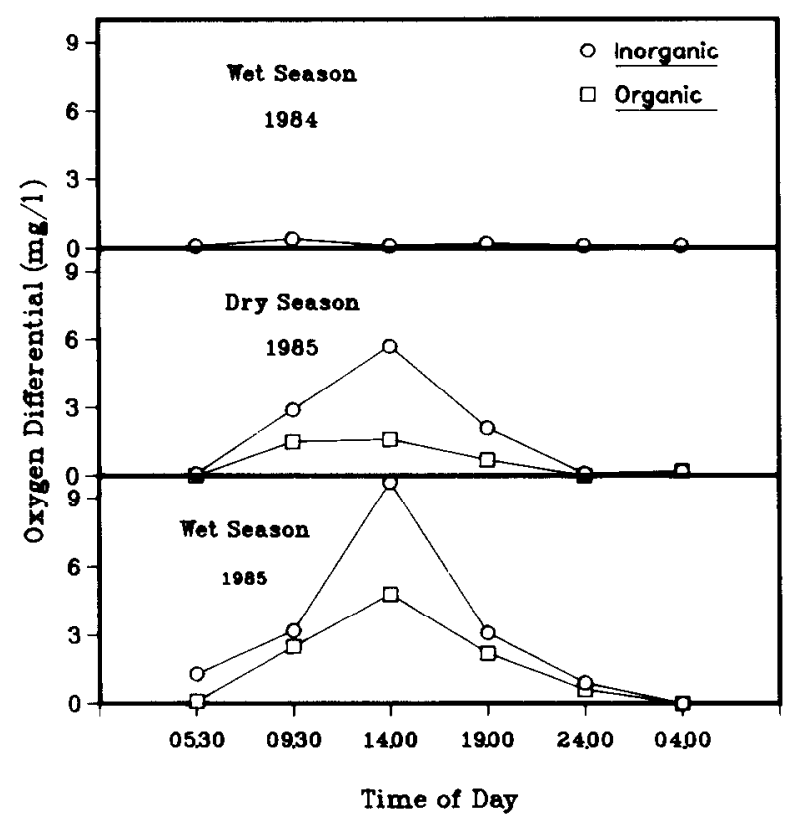

Fig. 6. Diel changes in oxygen differential (top vs. bottom) for organically and inorganically fertilized ponds averaged over months and ponds for a treatment. Wet season $1984=$ low input inorganic experiment; 1985 data $=$ high input organic or inorganic experiments for each season. 


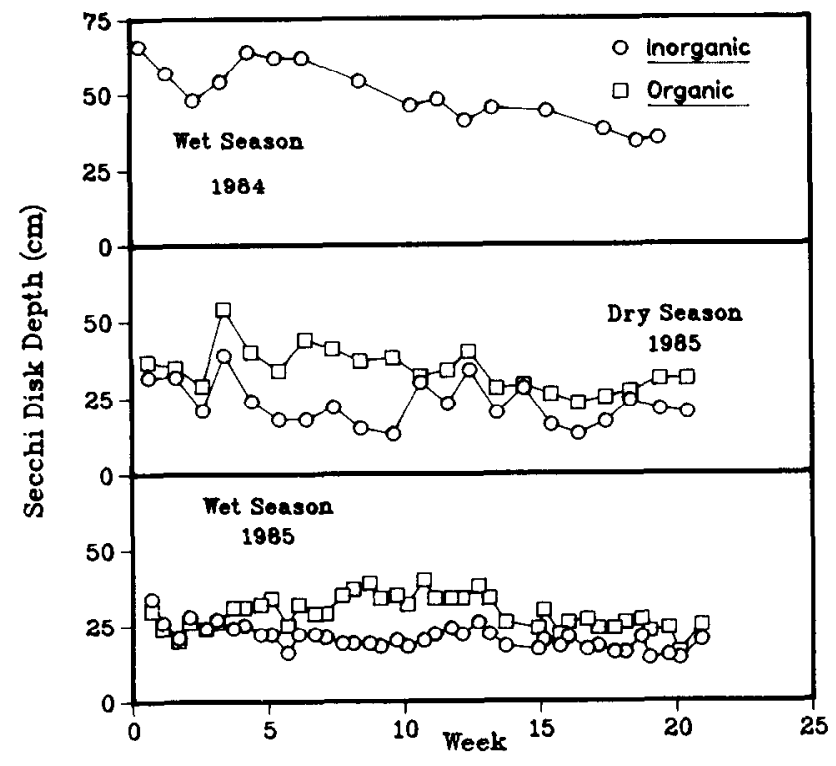

Fig. 7. Mean Secchi disk depth trends in experimental ponds. Wet season 1984=low input inorganic experiment; 1985 data = high input organic or inorganic experiments for each season.

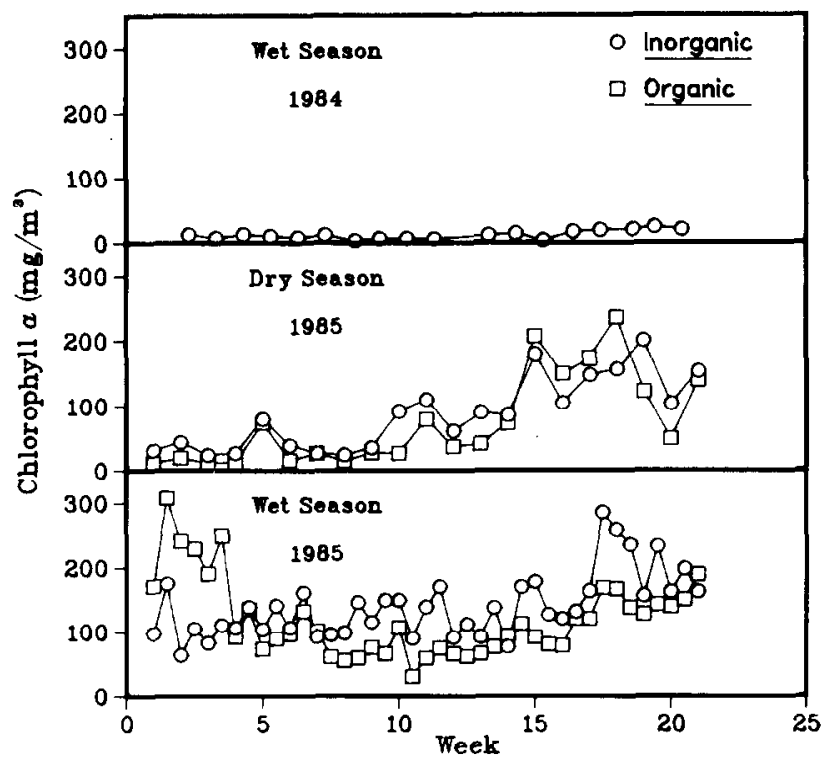

Fig. 8. Mean chlorophyll $a$ concentrations in experimental ponds. Wet season $1984=$ low input inorganic experiment; 1985 data $=$ high input organic or inorganic experiments for each season. 
duction with increased nutrient loading ( 1.6 vs. $12.2 \mathrm{~g} \mathrm{C} \mathrm{m}^{-3} \mathrm{~d}^{-1}$ for low and high loading, respectively), no significant difference between organically ( 11.5 $\left.\mathrm{g} \mathrm{C} \mathrm{m}^{-3} \mathrm{~d}^{-1}\right)$ and inorganically $\left(13.0 \mathrm{~g} \mathrm{C} \mathrm{m}^{-3} \mathrm{~d}^{-1}\right)$ fertilized ponds at high input, and significant monthly differences with no consistent time trends (Fig. 9).

Net monthly adult fish yield did not differ significantly between ponds of a treatment. High nutrient inputs led to a two-fold increase in monthly net adult yield $\left(9.0 \mathrm{~kg} \mathrm{ha}^{-1} \mathrm{~d}^{-1}\right)$ over low input ponds $\left(4.5 \mathrm{~kg} \mathrm{ha}^{-1} \mathrm{~d}^{-1}\right)$ (Table 1$)$. There was a significant difference in net adult yield and biomass between organically $\left(11.2 \mathrm{~kg} \mathrm{ha}^{-1} \mathrm{~d}^{-1}\right)$ and inorganically $\left(9.0 \mathrm{~kg} \mathrm{ha}^{-1} \mathrm{~d}^{-1}\right)$ fertilized ponds at high nutrient loading (Fig. 10). There were also significant differences in fish yield with month for all treatments, but these trends were inconsistent over time.

\section{Regression analyses}

Multiple regressions between temperature differential at $14.00 \mathrm{~h}$ as the dependent variable and air temperature, solar radiation, wind speed, rainfall, primary production, chlorophyll $a$, Secchi dish depth, and adult fish biomass as independent variables included only air temperature and solar radiation as significant predictors in the relationship $\left(R^{2}=0.60\right)$. However, this regression varied seasonally. During wet season 1985 , a significant relationship was

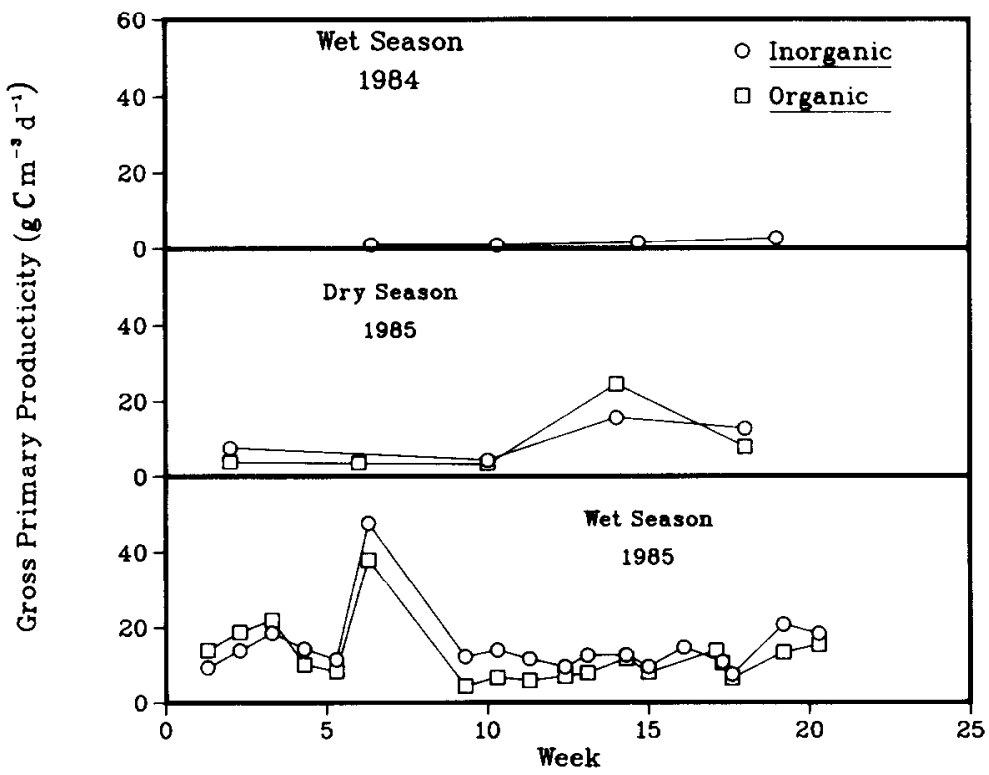

Fig. 9. Trends in mean net primary production in experimental ponds. Wet season $1984=$ low input inorganic experiment; 1985 data $=$ high input organic or inorganic experiments for each season. 


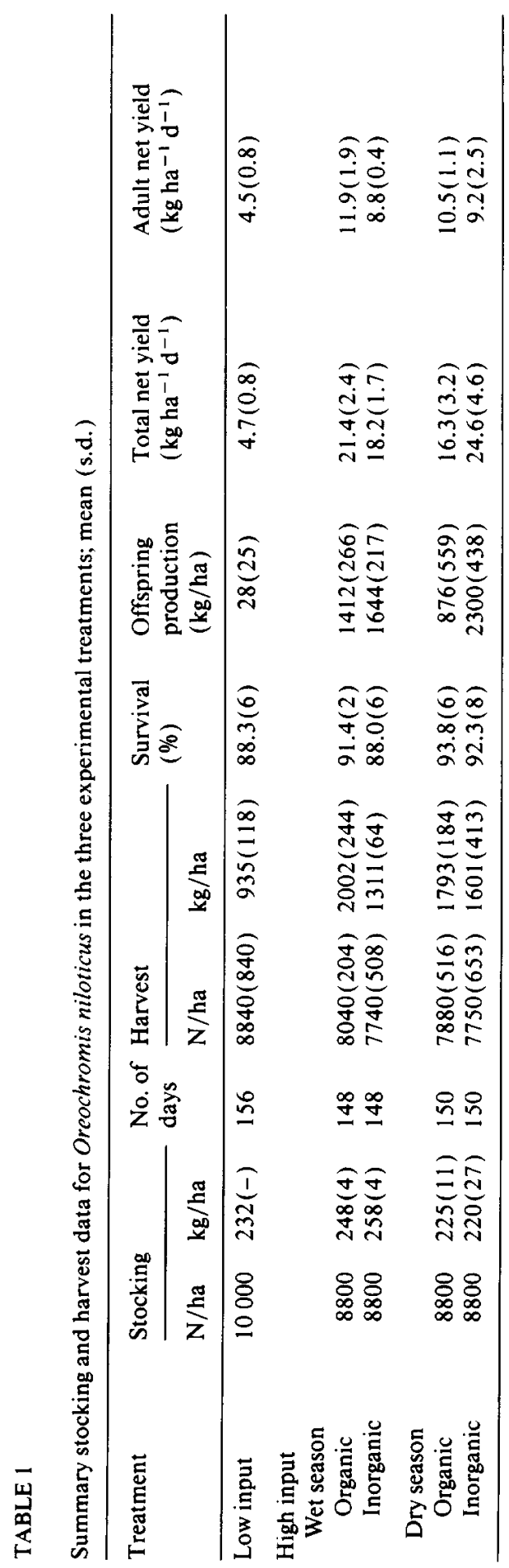




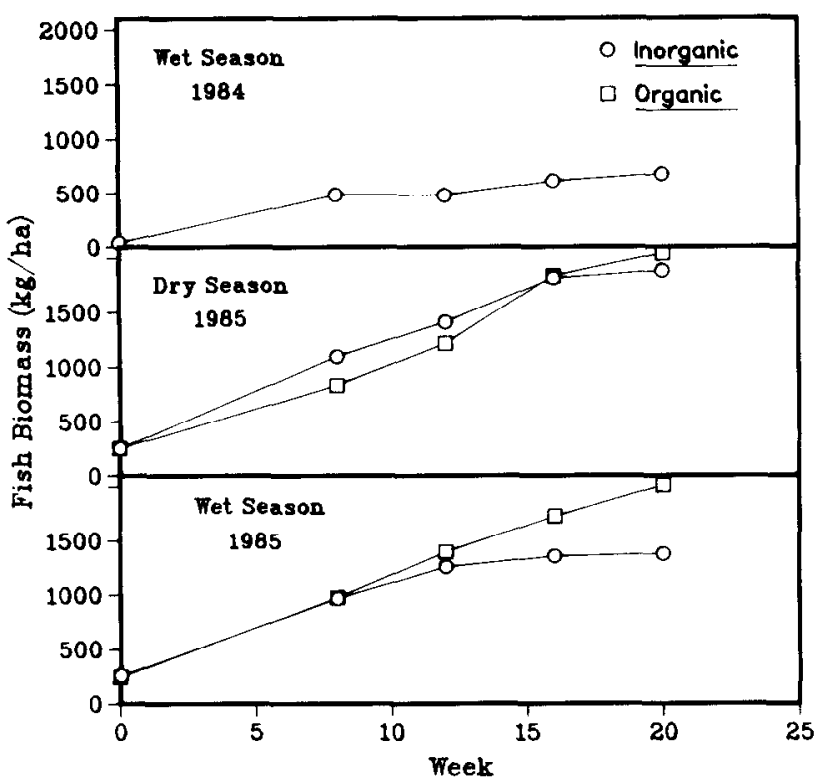

Fig. 10. Trends in mean fish biomass in experimental ponds. Wet season $1984=$ low input inorganic experiment; 1985 data $=$ high input organic or inorganic experiments for each season.

found $(P<0.05)$ which included air temperature, wind velocity, and rainfall $\left(R^{2}=0.99\right)$. During the 1985 dry season, solar radiation, air temperature, and rainfall explained nearly $100 \%$ of the variation in temperature differential at $14.00 \mathrm{~h}$.

Multiple regressions between oxygen differential at $14.00 \mathrm{~h}$ as the dependent variable and temperature differential, air temperature, wind velocity, solar radiation, daily rainfall, chlorophyll $a$ concentration, adult fish biomass, and Secchi disk depth as independent variables indicated that primary production alone explained $52 \%$ of the variance in oxygen differential at 14.00 h. When analyzed by experiment and season, results were inconclusive.

Primary production was significantly dependent on chlorophyll $a$ content, total phosphorus, total inorganic nitrogen, solar radiation, and rainfall ( $\mathrm{Ta}$ ble 2). Temperature and most other variables were not significantly correlated to primary production. Chlorophyll $a$ and rainfall had the highest coefficient of determination $\left(r^{2}\right)$, and none had an $r^{2}$ over 0.50 .

Monthly net adult fish yield was significantly correlated to primary production and rainfall (Table 2), and weakly correlated to Secchi disk depth, chlorophyll $a$ content, and solar radiation. Total net yield showed similar but weaker correlations in most cases. It was significantly correlated to chlorophyll $a$ content and primary production, and also weakly to total phosphorus, 
TABLE 2

Significant simple regression statistics for primary production, monthly net adult fish yield, or chlorophyll $a$ as dependent variables and other physical, chemical, and biological data as independent variables

\begin{tabular}{lrrrrl}
\hline Independent variable & \multicolumn{1}{c}{ Slope } & Intercept & \multicolumn{1}{c}{$r^{2}$} & $N$ & Significance \\
\hline Primary production & & & & & \\
Chlorophyll $a$ & 0.676 & 1868.3 & 0.46 & 111 & 0.000 \\
Rainfall & 0.594 & 5283.1 & 0.35 & 111 & 0.000 \\
Solar radiation & -0.541 & 37834.0 & 0.29 & 111 & 0.000 \\
Total P & 0.498 & 4876.2 & 0.25 & 99 & 0.000 \\
Total inorganic N & 0.328 & 4808.9 & 0.11 & 99 & 0.007 \\
Monthly net adult yield & & & & & \\
Rainfall & 0.630 & 3.98 & 0.40 & 111 & 0.000 \\
Primary production & 0.614 & 2.62 & 0.38 & 111 & 0.000 \\
Chlorophyll $a$ & 0.388 & 3.50 & 0.15 & 111 & 0.000 \\
Secchi disk depth & -0.384 & 10.70 & 0.15 & 111 & 0.000 \\
Solar radiation & -0.379 & 19.00 & 0.14 & 111 & 0.000 \\
Monthly total net yield & & & & & \\
Chlorophyll $a$ & 0.624 & 3.55 & 0.39 & 111 & 0.000 \\
Primary production & 0.557 & 4.74 & 0.31 & 111 & 0.000 \\
Secchi dish depth & -0.536 & 21.40 & 0.29 & 111 & 0.000 \\
Total inorganic N & 0.473 & 4.86 & 0.22 & 111 & 0.000 \\
Ammonia & 0.408 & 6.28 & 0.17 & 111 & 0.000 \\
Solar radiation & 0.408 & 33.80 & 0.17 & 111 & 0.000 \\
Total P & -0.388 & 20.30 & 0.15 & 111 & 0.000 \\
Chlorophyll $a$ & & & & & \\
Secchi dish depth & -0.82 & 12.15 & 0.67 & 110 & 0.000 \\
(log-log) & & & & & \\
\hline
\end{tabular}

Secchi desk depth, solar radiation, ammonia, and total inorganic nitrogen. Temperature, dissolved oxygen, and many other physical or chemical variables had no apparent effect on adult fish yield.

\section{DISCUSSION}

Analyses from the three experiments clearly indicate that increased fertilization rates resulted in larger adult fish yields, higher primary production, and larger dissolved oxygen variations. Manure loading rates at high input were high compared to a number of other studies (Tang, 1970; Schroeder, 1978; Noriega-Curtis, 1979). Growth of individual tilapia for the high input ponds (average $1.2 \mathrm{~g} / \mathrm{d}$ ) was below that reported for fertilization experiments by Stickney et al. (1979) (about $1.8 \mathrm{~g} / \mathrm{d}$ ). Thus, growth in fertilized ponds in Thailand might possibly be increased by higher fertilization rates.

Mean primary production (measured as gross production) in high input ponds (12.2 $\mathrm{g} \mathrm{C} \mathrm{m}^{-3} \mathrm{~d}^{-1}$ ) was similar to maxima of $10 \mathrm{~g} \mathrm{C} \mathrm{m}^{-3} \mathrm{~d}^{-1}$ for 
Israeli fish ponds (Hepher, 1962). Hepher's (1962) data indicated that most primary production occurred in the top $30 \mathrm{~cm}$ of a pond. Thus, the presently measured primary production values are probably maximum values rather than whole water column values. Regressions between primary production and other measured variables indicated that differences in rainfall $\left(r^{2}=0.35\right)$ and chlorophyll $a$ concentration $\left(r^{2}=0.46\right)$ accounted for most variance in primary production. Possibly the rapid use of available phosphorus and nitrogen by phytoplankton held those nutrients at low concentrations, thus obscuring any relationship with primary production. Although inorganically fertilized ponds often lose phosphorus to sediments (Hickling, 1962), inorganically treated ponds in this study had higher phosphorus concentrations in water than organically fertilized ponds (Fig. 4). Correlations between chlorophyll $a$ and primary production were relatively high in this study, which is consistent with previous work (Almazan and Boyd, 1978; Liang et al., 1981).

Regression analysis included rainfall as a factor influencing primary production and net adult yield, with a positive coefficient indicating increased levels with increased rainfall. Rainfall caused greater mixing and may have resulted in nutrient resuspension, as temperature stratification was negatively correlated with rainfall. Little runoff occurred, as the only watershed for each pond was the dyke itself. Thus, enrichment from runoff was unlikely. Rainfall is generally low in nutrients, and the level of nitrogen or phosphorus addition for a $1-\mathrm{cm}$ rainfall (Likens and Bormann, 1974) would be less than $0.001 \%$ of the fertilizer application of these nutrients in high input experiments.

Yield increased with an increased nutrient input, as did primary production. Net yield was higher in organically than in inorganically fertilized ponds, in spite of similar primary production and chlorophyll $a$ contents. This may indicate heterotrophic feeding by the fish, as manure adds detrital material and contributes directly to bacterial and zooplankton production (Tang, 1970). Microphagous tilapias are known to feed extensively on detritus (Bowen, 1979, 1982). An alternative explanation for decreased growth could be deleterious pH levels caused by inorganic fertilizer addition (Boyd, 1979). While $\mathrm{pH}$ was significantly different between organic and inorganic fertilized ponds ( 8.1 and 8.4 , respectively, ANOVA, $P<0.001$ ), the range of $\mathrm{pH}$ values was similar in both cases (7.0-9.1 in organic ponds, 7.4-9.5 in inorganic ponds) and never reached critically high or low levels (Balarin and Hatton, 1979).

Secchi disk depth was only moderately successful at predicting chlorophyll $a$ levels $\left(r^{2}=0.67 ; \log -\log\right.$ plot $)$, as was also found for catfish ponds in the USA (Boyd, 1979). One factor that influenced our measurements and correlations was the effect of fertilizer type on Secchi disk depth, as manure treatments had higher water clarity than inorganic treatments. Organic material is commonly used to remove clay turbidity from water (Swingle and Smith, 1947; Irwin and Stevenson, 1951). While algal-clay flocculation has 
also been demonstrated to reduce turbidity (Avnimelech et al., 1982), this mechanism probably did not influence the differences for Secchi disk depth found in high input experiments, as chlorophyll $a$ (estimates of algal biomass ) levels were not significantly different between the two fertilizer types.

Pond stratification occurred regularly, particularly for dissolved oxygen. Temperature stratification was correlated to wind velocity and pond heating rate, yet these variables only correlated moderately with temperature differential (multiple $R^{2}=0.60$ ). However, multiple regressions on seasonal data were very predictive, and also included rainfall. These highly predictive regressions for each season indicate that climatological factors, like wind and solar radiation, differ from wet to dry season. It was more difficult to account for oxygen stratification, which one would expect to be related to oxygen production and use as well as weather. In these analyses, primary production was the only independent variable included in this regression, and it explained only $52 \%$ of the variance in oxygen differential. Oxygen stratification was higher with high nutrient input than with low input, and higher in inorganically than organically fertilized ponds. The latter response may mainly be due to increased water clarity in organically fertilized ponds, allowing photosynthesis throughout the water column rather than only in surface waters as in inorganically fertilized ponds.

Monthly net adult fish yield was strongly correlated to rainfall and primary production. Similar correlations occurred between total net yield and primary production. The correlations to primary production were limited compared to studies done on a variety of other water bodies (McConnell et al., 1977; Oglesby, 1977; Liang et al., 1981 ). This may be partly due to our biased primary production analyses noted earlier. However, the positive correlation suggests that fish growth was at least partly related to ingestion of autochthonous material rather than predominantly heterotrophic food sources. Superior growth noted in organically fertilized ponds may also indicate heterotrophy, as also shown by Schroeder (1978) in manured ponds.

A problem in these analyses was timing of sampling, as time lags were ignored. For example, primary production for a given time period was considered dependent on nutrient levels at sampling. Data were combined into monthly means per pond, since the sampling frequency differed among the parameters, which might have obscured time lags and other transient relationships between factors. Fish yield analyses were further obscured by other problems. Monthly mortality was estimated from known numbers of fish only at the beginning and termination of each experiment. While mortality rate was assumed constant over time, losses may have occurred mainly over some small time interval. Mortality was generally small $(<10 \%)$, so errors from this assumption should have been minor. Monthly growth estimates were based on netted subsamples, while final fish size was determined from all fish in the pond. Thus, variation in tilapia production during the last month of 
each experiment was more likely due to biased estimates from previous months than to a different growth rate. While spawning was limited in most ponds due to stocking of manually sorted males, errors led to significant recruitment in some ponds. The biomass of young produced was occasionally quite large, but in general, it was less than $30 \%$ of the total yield (Table 1 ). Thus, reproduction probably resulted in increased variability within a treatment. However, correlations of factors to total net yield were no better than correlations to adult yield.

Nitrogen appeared to be the limiting nutrient in these experiments. The chicken manure used had NP percentages of $2.8: 4.5$ by weight. Chicken manure varies tremendously in composition, with other reported percentages of NP at 1.1:2.1 (Indonesia - Batterson et al., 1989), 2.2:1.6 (Honduras - Green et al., 1989), and 1.2:0.5 (United States - Boyd, 1979). Obviously, limiting nutrients will vary depending on manure composition, which varies locally. Similarly, the main form of nitrogen varied among treatments in this cxperiment, with $\mathrm{NH}_{3}$ predominating in inorganically and $\mathrm{NO}_{3}$ in organically fertilized ponds. As urea $\left(\mathrm{CO}\left(\mathrm{NH}_{2}\right)_{2}\right)$ was the form of inorganic nitrogen used, the importance of ammonia in inorganic treatments was mainly due to source. Possibly the uric acid, which is the main chicken excretory product, is oxidized in manure by exposure to air, or nitrified in water, allowing nitrate to be the major nitrogen form in manured ponds.

One final problem involved statistical interpretation of results. High and low input experiments were done during wet season 1985 and 1984, respectively. Thus, differences between treatments could include input effects, year effects, or both. There were strong climatic differences between years, particularly in seasonal rainfall (wet season 1984 had little rainfall). As rainfall strongly affected fish yield and primary production (Table 2), this biases comparisons between low and high input rate (done in different years). Since the differences between these treatments were generally quite large, the input effects likely predominated, and the interpretation of results was probably not largely affected by this problem. Organic and inorganic treatments were run simultaneously, avoiding this annual or seasonal bias.

These analyses indicate that, at least for the current data set, regression models using chemical, physical, and biological data only moderately predicted monthly primary production or net adult yield. This is unfortunate, because better correlations might allow comparisons between sites and prediction of yield based on practices to increase primary production or nutrient availability. Currently, yield models of fish culture are restricted to intensive systems (with feed) (Diana et al., 1988a; Ross et al., 1988). These models focus on bioenergetic parameters. Whether similar models can be used for managing fertilized aquaculture systems is uncertain. 


\section{ACKNOWLEDGEMENTS}

This project was conducted with cooperation of the National Inland Fisheries Institute, Department of Fisheries, Ministry of Agriculture and Cooperatives, Thailand. T. Bhukaswan, V. Sirsuwanatach, and S. Hiranyawat aided in logistics and data evaluation. The study was conducted at the Ayutthaya Freshwater Fisheries Station, which is directed by S. Ukatawewat. Data collection and laboratory analyses were done by V. Tansakul, S. Auworatham, W. Muthuwana, and assistants. B. Diana aided in data analysis and text preparation. This research is a component of the Pond Dynamics/Aquaculture CRSP supported by the Agency for International Development Grant No. DAN-4023-G-SS-2074-00, and by contributions from participating institutions. This is contribution 87:12 of the CRSP Aquaculture Project, and contribution 533 of the Great Lakes Research Division, University of Michigan.

\section{REFERENCES}

Almazan, G. and Boyd, C.E., 1978. Plankton production and Tilapia yield in ponds. Aquaculture, 15: 75-77.

APHA (American Public Health Association), 1980. Standard Methods For the Examination of Water and Wastewater, 13th edition. Washington, DC, $1134 \mathrm{pp}$.

Avnimelech, Y., Troeger, B.W. and Reed, L.W., 1982. Mutual flocculation of algae and clay: evidence and implications. Science, 216: 63-65.

Balarin, J.D. and Hatton, J.P., 1979. Tilapia, A Guide To Their Biology and Culture in Africa. Institute of Aquaculture, University of Stirling, Stirling, Great Britain, $174 \mathrm{pp}$.

Batterson, T.R., McNabb, C.D., Knud-Hansen, C.F., Eidman, H.M. and Sumatadinata, K., 1989. Pond Dynamics/Aquaculture Collaborative Research Data Reports, Vol. 3, No. 3. Indonesia Project: Cycle III of the CRSP Global Experiment. Oregon State University, Corvallis, OR.

Bowen, S.H., 1979. A nutritional constraint in detritivory by fishes: the stunted population of Sarotherodon mossambicus in Lake Sibaya, South Africa. Ecol. Monogr., 49: 17-31.

Bowen, S.H., 1982. Feeding, digestion, and growth - qualitative considerations. In: R.S.V. Pullin and R.H. Lowe-McConnell (Editors), The Biology and Culture of Tilapias. International Center for Living Aquatic Resources Management, Makati, Philippines, pp. 141-156.

Boyd, C.E., 1976. Nitrogen fertilizer effects on production of Tilapia in ponds fertilized with phosphorus and potassium. Aquaculture, 7: 385-390.

Boyd, C.E., 1979. Water Quality in Warm Water Fish Ponds. Auburn University Agriculture Experiment Station, Auburn, AL, USA.

Colman, J.A. and Edwards, P., 1987. Fecding pathways and environmental constraints in wastefed aquaculture: balance and optimization. In: P.J.W. Moriarity and R.S.V. Pullin (Editors), Detritus and Microbial Ecology in Aquaculture. International Center for Living Aquatic Resources Management, Manila, Philippines, pp. 240-281.

Diana, J.S., Kohler, S.L. and Ottey, D.R., 1988a. A yield model for walking catfish production in aquaculture systems. Aquaculture, 71:23-35.

Diana, J.S., Schneeberger, P.J. and Lin, C.K., 1988b. Relationships between primary produc- 
tion and yield of Tilapia in ponds. In: R.S.V. Pullin, T. Bhukaswan, K. Tonguthai and J.L. Maclean (Editors), The Second International Symposium on Tilapia in Aquaculture. ICLARM Conference Proceedings 15. International Center for Living Aquatic Resources Management, Manila, Philippines, pp. 1-6.

Fox, D.J. and Guire, K.E., 1976. Documentation for MIDAS. Statistical Research Laboratory, The University of Michigan, Ann Arbor, MI.

Goldman, J.C., 1980. Physiological processes, nutrient availability, and the concept of relative growth rate in marine phytoplankton ecology. In: P.G. Falkowski (Editor), Primary Productivity in the Sea. Plenum Press, New York, NY, pp. 179-194.

Green, B.W., Alvarenga, H.R., Phelps, R.P. and Espinoza, J., 1989. Pond Dynamics/Aquaculture Collaborative Research Data Reports, Vol. 6, No. 3. Honduras Project: Cycle III of the CRSP Global Experiment. Oregon State University, Corvallis, OR.

Hepher, B., 1962. Primary production in fishponds and its application to fertilization experiments. Limnol. Oceanogr., 7: 131-135.

Hickling, C.M., 1962. The Farming of Fish. Pergamon Press, London, Great Britain.

Irwin, W.H. and Stevenson, J.H., 1951. Physicochemical nature of clay turbidity with special reference to clarification and productivity of impounded waters. Okla. Agric. Mech. Coll. Bull., 48: I-54.

Liang. Y., Melack, J.M. and Wang, J., 1981. Primary production and fish yields in Chinese ponds and lakes. Trans. Am. Fish. Soc., 110: 346-350.

Likens, G.E. and Bormann, F.H., 1974. Acid rain: a serious regional environmental problem. Science, 184: 1176-1179.

Lin, C.K., Apinhapath, C. and Tansakul, V., 1988. Biological nitrogen fixation as a source of nitrogen inpul in fishponds. In: R.S.V. Pullin, T. Bhukaswan, K. Tonguthai, and J.L. Maclean (Editors), The Second International Symposium on Tilapia in Aquaculture. ICLARM Conference Proceedings 15. International Center for Living Aquatic Resources Management, Manila, Philippines, pp. 53-58.

Lind, O.T., 1979. Handbook of Common Methods in Limnology, 2nd edition. C.V. Mosby Company, St. Louis, MO, $199 \mathrm{pp}$.

McConnell, W., Lewis, S. and Olson, J.E., 1977. Gross photosynthesis as an estimator of potential fish production. Trans. Am. Fish. Soc., 106: 417-423.

Noriega-Curtis. P., 1979. Primary productivity and related fish yield in intensely manured fishponds. Aquaculture, 17: 335-344.

Oglesby, R.T., 1977. Relationships of fish yield to lake phytoplankton standing crop, production, and morphoedaphic factors. J. Fish. Res. Board Can., 34: 2271-2279.

Ross, L.G., McKinney, R.W. and Ross, B., 1988. Energy budgets for cultured tilapias. In: R.S.V. Pullin, T. Bhukaswan, K. Tonguthai and J.L. Maclean (Editors), The Second International Symposium on Tilapia in Aquaculture. ICLARM Conference Proceedings 15. International Center for Living Aquatic Resources Management, Manila, Philippines, pp. 83-89.

Schroeder, G.L., 1978. Autrotrophic and heterotrophic production of micro-organisms in intensely-manured fish ponds, and related fish yields. Aquaculture, 14: 303-325.

Stickney, R.R., Hesby, J.H., McGeachin, R.B. and Isbell, W.A., 1979. Growth of Tilapia nilotica in ponds with differing histories of organic fertilization. Aquaculture, 17: 189-194.

Swingle, H.S. and Smith, E.V., 1947. Management of farm fish ponds. Ala. Polytech. Inst. Agric. Exp. Stn., Bull., 254.

Tang, Y.A., 1970. Evaluation of balance between fishes and available fish foods in multispecies fish culture ponds in Taiwan. Trans. Am. Fish. Soc., 99: 708-718.

Wetzel, R.G. and Likens, G.E., 1979. Limnological Analyses. W.B. Saunders Co., Philadelphia, PA.

Yamada, R., 1986. Pond production systems: fertilization practices in warmwater fish ponds. In: J.E. Lannan, R.O. Smitherman and G. Tchobanoglous (Editors), Principles and Practices of Pond Aquaculture. Oregon State University Press, Corvallis, OR, pp. 97-110. 